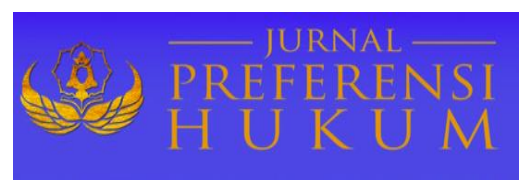

Jurnal Preferensi Hukum | ISSN: XXXX | E-ISSN: XXXX

Vol. 1 No. 1 - Juli 2020 hal. 120-127| Available online at https://www.ejournal.warmadewa.ac.id/index.php/juprehum

\title{
PEMBERIAN IZIN PEREDARAN MINUMAN BERALKOHOL BERDASARKAN PERATURAN GUBERNUR BALI NOMOR 1 TAHUN 2020
}

\author{
I Nyoman Sadhu Bramanta, Ida Ayu Putu Widiati, Luh Putu Suryani \\ Fakultas Hukum Universitas Warmadewa, Denpasar-Bali, Indonesia
}

\begin{abstract}
Abstrak
Usaha atau kegiatan di bidang perdagangan ada bermacam-macam, salah satunya adalah usaha perdagangan atau peredaran minuman beralkohol. Berdasarkan Peraturan Menteri Perdagangan Republik Indonesia Nomor 20/MDAG/PER/4/2014 Pasal 18 Ayat (1) bahwa setiap perusahaan yang memperdagangkan minuman beralkohol wajib untuk memiliki SIUP-MB. Minuman beralkohol hanya dapat diperdagangkan oleh perusahaan yang telah memiliki surat izin usaha perdagangan minuman beralkohol sesuai dengan penggolongannya. Penelitian ini penting dilakukan dengan tujuan untuk mengetahui mekanisme pemberian izin peredaran minuman beralkohol berdasarkan Peraturan Gubernur Bali Nomor 1 Tahun 2020 dan implikasi Peraturan Gubernur Bali Nomor 1 Tahun 2020 terhadap pelaku usaha perdagangan minuman beralkohol. Penelitian ini merupakan penelitian hukum normatif, yaitu dengan menggunakan pendekatan peraturan perundang-undangan. Mekanisme pemberian izin peredaran minuman beralkohol berdasarkan Peraturan Gubernur Bali Nomor 1 Tahun 2020 yaitu pelaku usaha harus menempuh prosedur dan memenuhi persyaratan tertentu dalam memohon SIUP-MB, selanjutnya mengajukan permohonan izin kepada Dinas Perdagangan dan Perindustrian Provinsi, setelah dilakukannya penerbitan usaha oleh Dinas Perdagangan dan Perindustrian, barulah pelaku usaha dapat melakukan usaha perdagangan yang dikehendaki. Implikasi Peraturan Gubernur Bali Nomor 1 Tahun 2020 Tentang tata kelola minuman fermentasi dan/atau destiasi khas bali terhadap pelaku usaha perdagangan minuman beralkohol sangat besar dirasakan manfaatnya, para perajin atau petani minuman fermentasi dan/atau destilasi khas bali memiliki kepastian hukum dan kepastian berusaha dalam melakukan kegiatan produksi minuman fermentasi dan destilasi khas bali.
\end{abstract}

Kata Kunci: Distributor; Minuman Beralkohol; Perizinan

\begin{abstract}
There are various kinds of businesses or activities in the field of trade, one of which is a trade or distribution of alcoholic drinks. Based on the Regulation of the Minister of Trade of the Republic of Indonesia Number 20 / M-DAG IPER / 4/2014 Article 18 Paragraph (1) that every company that trades alcoholic drinks is required to have SIUPMB. Alcoholic drinks can only be traded by companies that already have a business license for alcoholic drinks in accordance with their classification. This research is important to be carried out with the aim to find out the mechanism for granting alcoholic beverage distribution license based on Bali Governor's Regulation No. 1 of 2020 and the implications of Bali's Governor's Regulation No. 1 of 2020 to alcoholic beverage trade businesses. This research is a normative legal research, namely by using the statutory approach. The mechanism for granting licenses for the distribution of alcoholic drinks based on Bali Governor Regulation No. 1 of 2020 is that business operators must follow procedures and fulfill certain requirements in applying for SIUP-MB, then submit a permit application to the Provincial Trade and Industry Office, after the issuance of a business by the Trade and Industry Office, then the business actor can carry out the desired trading business. Implications of Bali Governor Regulation Number 1 of 2020 Regarding the management of fermented drinks and/or distinctive distinctive Bali for the business of the alcoholic beverage trade, the benefits are felt, the crafters or farmers of fermented drinks and/or distinctive distinctive Bali have legal certainty and certainty of trying to do fermented and distillation drinks production activities typical of Bali.
\end{abstract}

Keywords: Alcoholic Beverages; Distributor; Licensing 


\section{PENDAHULUAN}

Seiring dengan perkembangan zaman yang semakin pesat di era globalisasi sekarang ini, menuntut masyarakat untuk lebih berpikir maju kedepan guna untuk memenuhi kebutuhan hidupnya. Salah satu cara untuk memenuhi kebutuhan hidup tersebut, banyak masyarakat saat ini yang mulai menggeluti suatu usaha, salah satunya adalah usaha perdagangan. Perdagangan adalah seluruh kegiatan usaha dagang yang dilakukan oleh pelaku usaha atau badan usaha dalam pembelian dan penjualan atau pertukaran barang dan jasa. Perdagangan pada umumnya ialah pekerjaan membeli barang dari suatu tempat atau pada suatu waktu dan menjual barang itu di tempat lain atau pada waktu berikutnya dengan maksud untuk memperoleh keuntungan (Hasyim 2018). Usaha atau kegiatan di bidang perdagangan ada bermacam- macam, salah satunya adalah usaha perdagangan atau peredaran minuman beralkohol. Meskipun minuman beralkohol dalam masyarakat biasa disebut dengan minuman keras (Maryadi, Bahiej, and Tahir 2016) tetapi minuman beralkohol tetap diedarkan. Peredaran minuman beralkohol adalah kegiatan menyalurkan minuman beralkohol baik yang dilakukan oleh distributor, sub distributor, pengecer, atau penjual langsung. Peredaran minuman beralkohol saat ini bisa dikatakan terbilang cukup bebas di masyarakat, karena saat ini disetiap daerah sangat mudah dijumpai toko-toko kecil hingga toko-toko besar yang menjual minuman beralkohol. Jenis minuman beralkohol yang di perjualbelikan pun beragam, mulai dari minuman beralkohol buatan pabrik hingga minuman beralkohol tradisional.

Dalam menjalankan usaha atau kegiatan perdagangan minuman beralkohol ini tentunya harus memiliki izin, karena izin merupakan hal yang sangat diperlukan oleh seseorang atau pelaku usaha yang akan memulai suatu kegiatan usaha. Izin dapat diartikan sebagai perbuatan hukum administrasi negara bersegi satu yang menghasilkan peraturan dalam hal kontreo berdasarkan persyaratan dan prosedur sebagaimana ditetapkan oleh ketentuan peraturan perundang-undangan yang berlaku (Sjacran Basah 1995). Berdasarkan Peraturan Menteri Perdagangan Republik Indonesia Nomor 20/M-DAG/PER/4/2014 tentang pengendalian dan pengawasan terhadap pengadaan, peredaran, dan penjualan minuman beralkohol pasal 18 ayat (1) bahwa setiap perusahaan yang bertindak sebagai distributor, sub distributor, pengecer, atau penjual langsung yang memperdagangkan minuman beralkohol wajib untuk memiliki surat izin usaha perdagangan minuman beralkohol atau yang biasa disebut SIUP-MB. Surat izin usaha perdagangan minuman beralkohol ini adalah salah satu syarat yang wajib dimiliki oleh pelaku usaha yang melakukan kegiatan usaha perdagangan minuman beralkohol agar tidak terjadi masalah pada perizinan pada saat kegiatan usaha tersebut berjalan. Dengan diterbitkannya Peraturan Gubernur Bali No 1 Tahun 2020 tentang tata kelola minuman fermentasi dan atau destilasi khas bali diharapkan agar para pelaku usaha perdagangan minuman beralkohol memiliki izin dalam menjalankan kegiatan usahanya, baik itu yang memperdagangkan minuman beralkohol buatan pabrik (import) maupun minuman beralkohol tradisional. Peraturan Gubernur ini dikeluarkan dengan tujuan untuk membangun standardisasi produksi untuk menjamin keamanan dan legalitas produk minuman fermentasi dan atau destilasi khususnya khas bali.

Izin merupakan sarana hukum yang berwujud keputusan yang digunakan oleh pemerintah untuk mengurus atau mengatur peristiwa-peristiwa konkret yang dihadapi oleh masyarakat dalam memenuhi kebutuhan hidupnya. Maka dari itu segala bentuk kegiatan usaha perdagangan termasuk kegiatan usaha perdagangan minuman beralkohol wajib untuk memiliki izin usaha perdagangan. Minuman beralkohol hanya dapat diperdagangkan oleh pelaku usaha atau perusahaan yang telah memiliki surat izin usaha perdagangan minuman beralkohol atau SIUP-MB sesuai dengan penggolongannya. Pemerintah daerah berwenang melakukan pengendalian peredaran minuman tersebut dengan menerapkan penegakan hukum terhadap kegiatan usaha yang melanggar izin usaha dengan menjual minuman beralkohol tradisional (Alfianti 2018). Meskipun produk minuman beralkohol berkontribusi cukup besar terhadap penerimaan negara yang bersumber dari cukai, akan tetapi dalam hal pengadaan, peredaran, dan penjualannya harus tetap diawasi dan dibatasi oleh pemerintah, agar peredarannya sesuai dengan peraturan perundangundangan yang berlaku.

Penelitian yang mengkaji tentang Pengendalian Peredaran Minuman Beralkohol di Wilayah Hukum Polresta Denpasar mengungkapkan bahwa pelaksanaan pengendalian peredaran minuman beralkohol di wilayah hukum POLRESTA Denpasar mengacu pada Peraturan Daerah Provinsi Bali Nomor 5 Tahun 2012, Peraturan Daerah Kota Denpasar Nomor 11 Tahun 2002, dan Peraturan Daerah Kabupaten Badung 
Nomor 1 Tahun 2013. Dari ketiga Perda ini hanya Perda Provinsi Bali saja yang mencantumkan tentang peredaran minuman tradisional beralkohol (Zanivah, Wairocana, and Sudiarta 2016). (Khumairoh 2016) dalam penelitian tentang pelaksanaan kebijakan pemerintah Kota Bandar Lampung tentang pengendalian dan pengawasan terhadap pengadaan dan penjualan minuman beralkohol di minimarket menjelaskan bahwa minuman beralkohol hanya dapat diperjual belikan di Supermarket, Hypermarket, Restoran, Bar dan Hotel, sementara yang peredaraannya untuk kota Bandar Lampung diatur dalam Peraturan Daerah kota Bandar Lampung Nomor 11 Tahun 2008. Pada penelitian lain, ditemukan bahwa tahapan mekanisme perijinan KPPBC XXX tidak memperhatikan ketentuan PMK 201/PMK.04/2008, selain itu karena kurangnya pengawasan KPPBC XXX terhadap pengusaha TPE yang sudah berijin mengakibatkan hampir setengah dari pengusaha TPE berijin di Kota XXX tidak lagi memenuhi ketentuan yang berlaku (Cahyo and Adhitama 2019).

Dari latar belakang diatas, maka terdapat dua permasalahan hukum yaitu bagaimana mekanisme pemberian izin peredaran minuman beralkohol berdasarkan Peraturan Gubernur Bali Nomor 1 Tahun 2020? Dan bagaimana implikasi Peraturan Gubernur Bali Nomor 1 Tahun 2020 terhadap pelakuusaha perdagangan minuman beralkohol? Dengan demikian, didapati tujuan penelitian, yaitu untuk mengetahui mekanisme pemberian izin peredaran minuman beralkohol berdasarkan Peraturan Gubernur Bali Nomor 1 Tahun 2020 dan implikasi Peraturan Gubernur Bali Nomor 1 Tahun 2020 terhadap pelaku usaha perdagangan minuman beralkohol.

\section{METODE}

Pencarian informasi secara normatif berpatokan pada peraturan pemerintah yang berfokus pada minuman beralkohol sebagai objeknya dan analisis dalam Informasi yang didapat secara konseptual berkaitan dengan penulisan ini. Penelitian hukum normatif adalah hukum kepustakaan yang mengacu pada norma hukum yang terdapat dalam peraturan Perundang- undangan (Waluyo 2002).

Penulis dalam menyelesaikan skripsi dengan tidak menyimpang dari hukum positif dan Penelitian melalui permasalahan yang dipaparkan diatas. Pendekatan perundangan - undangan adalah melakukan suatu penelitian dengan berpatokan pada undang - undang sebagai dasar penulisan skripsi. Pendekatan kasus dilakukan guna melihat, mencatat dan memahami permasalahan yang diangkat dalam skripsi ini dengan tidak keluar dari zona hukum positif.

Penelitian ini menggunakan metode normatif dan kualitatis dimana dalam pengerjaannya peneliti menelaah isu hukum dengan didasari peraturan - peraturan hukum positif di Indonesia.

\section{HASIL DAN PEMBAHASAN}

Berbicara mengenai minuman beralkohol tentu tidak dapat dipisahkan dari sejarah perkembangan minuman beralkohol itu sendiri, sejarah minuman beralkohol sama panjangnya dengan sejarah peradaban manusia. Para arkeolog menyebutkan bahwa minuman beralkohol muncul pertama kali pada zaman peradaban mesir kuno, yang kemudian berlanjut pada periode yunani kuno dan romawi kuno. Dari sinilah minuman beralkohol mulai dan terus berkembang menjadi bagian dari peradaban manusia. Dari sejarah itulah muncul berbagai macam jenis minuman beralkohol di berbagai negara, yang masing-masing dengan ciri khas pembuatannya yang tidak lepas dari budaya setempat.

Alkohol merupakan suatu persoalan yang cukup dilematis saat ini, itu disebabkan karena minuman beralkohol saat ini telah menjadi bagian dari budaya dan adat istiadat pada beberapa tempat di Indonesia. Masyarakat pulau Bali menjadi salah satu contohnya, masyarakat di Bali sudah sejak lama menjadikan minuman beralkohol sebagai sarana dan bagian dalam budaya, adat istiadat, dan upacara keagamaan. Itu terbukti dengan diterbitkannya Peraturan Gubernur Bali No 1 Tahun 2020 tentang tata kelola minuman fermentasi dan atau destilasi khas bali, dimana pemerintah provinsi bali telah memutuskan untuk melegalkan minuman beralkohol, khususnya minuman beralkohol tradisional khas bali. Peraturan Gubernur ini terbit dilatarbelakangi karena minuman beralkohol fermentasi khas bali, seperti arak, tuak, dan brem bali merupakan salah satu dari sumber daya keragaman budaya bali.

Dalam ilmu kimia, alkohol atau alkanol adalah nama yang umum untuk senyawa organik yang memiliki gugus hidroksil $(-\mathrm{OH})$ yang terikat pada atom karbon, yang ia sendiri terikat pada atom hidrogen 
dan atau atom karbon lain. Alkohol yang biasa dijumpai dalam minuman keras adalah ethyl alcohol atau disebut juga etanol, dengan rumus kimia $\mathrm{C} 2 \mathrm{H} 5 \mathrm{OH}$ namun biasannya lebih sering disebut dengan alkohol saja. Jenis senyawa alkohol lainnya adalah metanol, propanol, butanol, dan lain sebagainya (Hartati Nurwijaya and Ikawati 2009). Sedangkan minuman beralkohol adalah semua jenis minuman yang mengandung etanol atau yang biasa disebut grain alcohol. Hal ini disebabkan karena senyawa organik yang digunakan sebagai bahan dasar pada pembuatan minuman beralkohol adalah etanol dan bukan metanol atau senyawa alkohol lainnya. Etanol pada minuman beralkohol sudah dikonsumsi oleh manusia sejak zaman prasejarah dengan berbagai tujuan dan kegunaan yang berbeda- beda. Bila dikonsumsi berlebihan, minuman beralkohol dapat menimbulkan efek samping gangguan mental organik (GMO), yaitu gangguan dalam fungsi berpikir, merasakan, dan berprilaku. Timbulnya GMO itu disebabkan oleh reaksi langsung dari alkohol pada sel-sel saraf pusat. Karena sifat adiktif alkohol itu, orang yang meminumnya lamakelamaan tanpa sadar akan menambah takaran atau dosis sampai pada dosis keracunan atau mabuk.

Pengertian minuman beralkohol di Indonesia secara resmi diatur dalam Peraturan Presiden Republik Indonesia Nomor 74 Tahun 2013 tentang pengendalian dan pengawasan minuman beralkohol, dimana dalam pasal 1 ayat (1) peraturan tersebut menyebutkan bahwa minuman beralkohol adalah minuman yang mengandung etil alkohol atau etanol $(\mathrm{C} 2 \mathrm{H} 5 \mathrm{OH})$ yang diproses dari bahan hasil pertanian yang mengandung karbohidrat dengan cara fermentasi dan destilasi atau fermentasi tanpa destilasi. Sedangkan di dalam pasal 3 ayat (1) Peraturan Presiden No 74 Tahun 2013 tersebut, minuman beralkohol dikelompokkan dalam tiga jenis golongan yang dibedakan berdasarkan kadar alkohol atau etanol yang terkandung di dalamnya, baik itu minuman beralkohol yang berasal dari produksi dalam negeri atau asal impor. Pengaruh mengkonsumsi minuman beralkohol secara berlebihan tidak hanya berdampak pada kesehatan tubuh, akan tetapi berdampak juga pada masyarakat, seperti timbulnya gangguan keamanan dan ketertiban di dalam masyarakat dan kecemasan yang terjadi dengan timbulnya banyak tindak kejahatan akibat mengkonsumsi minuman beralkohol secara berlebihan. Maka dari itu diperlukan izin untuk mengatur peredaran minuman beralkohol.

Membicarakan soal perizinan, tentunya tidak dapat dilepaskan dari urusan pemerintahan. Karena urusan pemerintahan ini menyangkut kewenangan untuk menerbitkan izin yang menjadi kewenangan lembaga, dinas, atau badan pemerintahan tertentu, baik itu di pusat ataupun yang sudah dilimpahkan kepada pemerintah daerah. Hal ini sebagai akibat penerapan otonomi daerah, yang mana terdapat urusan yang tetap dikelola oleh pemerintah pusat serta ada pula urusan yang sudah dilimpahkan atau dimandatkan kepada pemerintah daerah untuk mengurusnya. Izin merupakan suatu bentuk ketetapan pemerintahan yang paling sering diputuskan dalam bidang hukum tata usaha untuk mengarahkan dan memberikan kendali kegiatan usaha warga. Dalam fungsinya sebagai elemen kebijakan pemerintahan, maka hakikat izin adalah sebagai bentuk konkret perbuatan hukum pemerintahan yang bersifat sepihak yang diputuskan berdasarkan kewenangan yang dimiliki untuk membolehkan suatu kegiatan usaha menurut hukum bagi orang atau badan hukum. Dengan kata lain, instrumen perizinan sangat diperlukan pemerintah untuk mengkonkretisasi kewenangan untuk mengatur kegiatan usaha yang dilakukan masyarakat dengan tujuan-tujuan tertentu (Nuriyanto A. Daim 2019). Aspek perizinan adalah salah satu sarana hukum yang diperuntukkan melakukan pengendalian aktivitas usaha yang dilakukan oleh masyarakat khususnya dalam lingkup hukum tata usaha, sehingga izin berperan sebagai perangkat pemerintahan yang bersifat pencegahan melalui sarana kepatuhan hukum yang dipergunakan menjadi sarana hukum tata usaha untuk pengendalian aktivitas usaha yang dilakukan oleh masyarakat dengan kewajiban pemenuhan persyaratan-persyaratan yang telah ditentukan.

Pembuatan dan penerbitan ketetapan izin merupakan tindakan hukum pemerintahan, sebagai tindakan hukum maka harus didasarkan pada wewenang yang diberikan oleh peraturan perundangundangan yang berlaku. Berbagai ketentuan penyelenggaraan pemerintahan dapat diketahui bahwa mulai dari administrasi negara tertinggi sampai dengan administrasi negara terendah berwenang memberikan izin. Terlepas dari beragamnya lembaga pemerintahan atau administrasi negara yang mengeluarkan izin, yang pasti adalah bahwa izin hanya boleh dikeluarkan oleh lembaga pemerintahan. Antara pemerintah dan masyarakat terjalin suatu hubungan timbal balik, yakni pada satu sisi masyarakat mempengaruhi pemerintah dalam menjalankan tugasnya, pada sisi lain pemerintah memberi pengaruh tertentu pada 
masyarakat melalui tugas mengurus dan mengatur. Pada dasarnya pemerintah selaku penyelenggara pelayanan publik dalam membuat kebijakan atau menerbitkan suatu izin selalu didasari pada dasar hukum yang tepat dan sesuai dengan kebijakan atau izin yang akan dibuat. Dasar hukum ini berfungsi sebagai pedoman dan landasan dalam membuat suatu kebijakan atau izin, tanpa didasari oleh dasar hukum yang tepat maka kebijakan atau izin yang dikeluarkan akan menjadi cacat hukum dan tidak dapat berfungsi sebagaimana mestinya, maka dari itu dasar hukum yang tepat sangat diperlukan dalam membuat suatu kebijakan. Pada umumnya kebijakan atau izin yang dikeluarkan tersebut dibuat dan ditentukan secara sepihak oleh pemerintah selaku penyelenggara pelayanan publik. Meskipun demikian, pemerintah tidak boleh membuat atau menentukan suatu kebijakan menurut kehendaknya sendiri secara sewenang-wenang, tetapi harus sejalan dengan dasar hukum atau peraturan perundang-undangan yang menjadi dasar dari kebijakan atau izin yang dibuat tersebut. Untuk mengetahui pelayanan yang tepat bagi rakyatnya, semua kebijakan yang dibuat harus melibatkan dan memihak rakyat. Disini dibutuhkan kepekaan terhadap setiap permasalahan dan kebutuhan masyarakat oleh pengambil kebijakan. Dalam proses pembuatan kebijakan diperlukan kerjasama yang baik antara masyarakat dan pemerintah untuk bersama-sama merumuskan serta membuat kebijakan. Perdagangan dan peredaran minuman beralkohol yang semakin marak terjadi saat ini di dalam masyarakat mengharuskan pemerintah untuk melakukan pengaturan terhadap izin peredaran minuman beralkohol. Saat ini, pengaturan yang ada masih tersebar di beberapa tingkat peraturan perundang-undangan dengan muatan pengaturan masih sectoral (Lestari 2016). Pentingnya pengaturan ini, sebab minuman beralkohol menimbulkan berbagai macam persoalan, bukan hanya terhadap individu peminum, namun juga telah meresahkan masyarakat secara umum (Huda, Ghafur, and Ridho 2015). Surat izin usaha perdagangan minuman beralkohol merupakan syarat yang wajib dimiliki oleh perusahaan atau distributor yang melakukan kegiatan usaha perdagangan minuman beralkohol. Di provinsi Bali, peraturan yang menjadi dasar hukum terhadap pengaturan izin peredaran minuman beralkohol yaitu sebagai berikut:

1. Peraturan Presiden Republik Indonesia Nomor 74 Tahun 2013 tentang pengendalian dan pengawasan minuman beralkohol;

2. Peraturan Menteri Perdagangan Republik Indonesia Nomor 20/M- DAG/PER/4/2014 tentang pengendalian dan pengawasan terhadap pengadaan, peredaran, dan penjualan minuman beralkohol; dan

3. Peraturan Gubernur Bali Nomor 1 Tahun 2020 tentang tata kelola minuman fermentasi dan/atau destilasi khas bali;

Peraturan tersebut diatas merupakan dasar hukum yang digunakan dalam pengaturan izin peredaran minuman beralkohol di Provinsi Bali. Setelah dikeluarkan dan diundangkannya Peraturan Gubernur Bali Nomor 1 Tahun 2020, Pemerintah Provinsi Bali telah memberikan payung hukum kepada para perajin atau petani minuman fermentasi dan destilasi khas Bali dengan melegalkan minuman fermentasi tradisional khas bali seperti arak, tuak, dan brem bali. Meskipun telah dilegalkan, bukan berarti dalam hal penjualan dan peredarannya dapat dilakukan secara bebas tanpa mengantongi izin, dilegalkannya minuman fermentasi khas bali ini dalam artian pemerintah memberikan kepastian hukum dan kepastian dalam berusaha bagi para perajin atau petani yang memproduksi minuman fermentasi dan destilasi khas bali tersebut. Penjualan minuman beralkohol tradisional khas bali ini selanjutnya akan melibatkan koperasi sebagai Mitra Usaha, dimana para perajin atau petani akan menjual minuman hasil produksinya kepada koperasi, koperasi disini berperan sebagai pengepul hasil produksi dan selanjutnya koperasi akan menjual bahan baku atau hasil produksi para perajin tersebut kepada produsen atau pabrik. Selanjutnya produsen atau pabrikan akan mengolah lebih lanjut bahan baku atau hasil produksi tersebut agar bisa terstandarisasi, lebih terjaga kehigienisannya, dan selanjutnya dilakukan pelekatan pita cukai pada saat dikeluarkan dari pabrik. Hal tersebut perlu dilakukan agar produk minuman fermentasi dan/atau destilasi khas bali dapat bersaing dengan tradisional spirit lain di dunia. Minuman tradisional khas bali tersebut hanya dapat diperdagangkan pada tempat-tempat tertentu di bali, sedangkan untuk diluar bali atau untuk ekspor disesuaikan dengan ketentuan peraturan perundang-undangan yang berlaku. Penerbitan Peraturan Gubernur ini merupakan suatu persetujuan dari Kementerian Dalam Negeri, dengan maksud untuk melindungi sumber daya keragaman budaya Bali. Tujuan dibuat dan diterbitkannya Peraturan Gubernur ini didasarkan karena minuman beralkohol tradisional khas Bali sudah menjadi bagian dalam kebudayaan masyarakat bali, selain 
itu minuman beralkohol tradisional juga digunakan oleh masyarakat Bali sebagai sarana dalam suatu ritual adat atau upacara keagamaan. Hal tersebut sudah dilakukan oleh masyarakat bali sejak lama dan masih dipertahankan sampai saat ini. Tujuan dari diterbitkannya Peraturan Gubernur tersebut selanjutnya diatur lebih jelas di dalam Pasal 3 Peraturan Gubernur Bali Nomor 1 Tahun 2020 Tentang Tata Kelola Minuman Fermentasi dan/atau Destilasi Khas Bali.

Dengan adanya Peraturan Gubernur Bali Nomor 1 Tahun 2020 ini, implikasinya terhadap pelaku usaha minuman beralkohol di Bali sangat dirasakan manfaatnya, khususnya bagi para pelaku usaha atau perajin minuman fermentasi dan destilasi khas Bali. Dengan adanya Peraturan Gubernur tersebut para pelaku usaha telah memiliki kepastian hukum dan kepastian berusaha dalam melakukan kegiatan produksi minuman fermentasi dan/atau destilasi khas Bali. Berbeda jauh dengan sebelum adanya Peraturan Gubernur ini, sebelum adanya Peraturan Gubernur ini para perajin kerap dirazia polisi dikarenakan mereka dianggap melakukan kegiatan yang ilegal atau melanggar hukum. Namun dengan adanya Peraturan Gubernur Nomor 1 Tahun 2020 ini para pelaku usaha minuman beralkohol sangat merasa terbantu, dikarenakan mereka telah memiliki payung hukum dalam menjalankan kegiatan usahanya. Sesuai dengan tujuan utama dari Peraturan Gubernur Bali Nomor 1 Tahun 2020 ini yaitu untuk mengangkat produk minuman tradisional budaya Bali agar mampu bersaing atau sejajar dengan minuman tradisional lain di dunia, sehingga terjadi peningkatan dalam produksi, terciptanya lapangan pekerjaan baru, dan tentunya dengan memanfaatkan minuman fermentasi dan/ atau destilasi khas bali dapat dijadikan sebagai sumber daya ekonomi untuk meningkatkan kesejahteraan masyarakat Bali, khususnya bagi para perajin atau petani. Namun yang menjadi catatan penting yaitu bagaimana Pemerintah Provinsi Bali dalam mengatur pola perilaku masyarakat dalam mengkonsumsi produk minuman fermentasi dan/atau destilasi khas Bali ini agar tidak terjadi penyalahgunaan dalam pemanfaatannya.

Permohonan izin usaha perdagangan minuman beralkohol umumnya harus menempuh prosedur dan memenuhi persyaratan-persyaratan tertentu yang ditentukan secara sepihak oleh pemerintah selaku pemberi izin. Persyaratan-persyaratan dalam pengurusan izin tersebut merupakan suatu pengendali dalam memfungsikan izin itu sebagai alat untuk mengawasi aktivitas atau kegiatan masyarakat, dan perbuatan yang dimintakan izin adalah perbuatan yang memerlukan pengawasan khusus, dan dalam memberikan izin menjual minuman beralkohol ditetapkan sejumlah syarat-syarat yang harus dipenuhi oleh pemohon izin. Setiap jenis aktivitas atau kegiatan usaha perdagangan wajib untuk memiliki izin usaha, tidak terkecuali bagi perusahaan atau pelaku usaha perdagangan minuman beralkohol. Namun faktanya di lapangan saat ini masih banyak ditemui perusahaan atau pelaku usaha yang tidak memiliki izin dalam menjalankan kegiatan usaha perdagangan, sehingga minuman beralkohol baik modern maupun tradisional beredar secara illegal (Patawari and Limpo 2020). Hal yang membuat perusahaan atau pelaku usaha perdagangan minuman beralkohol tidak memiliki izin usaha tersebut dapat disebabkan oleh beberapa faktor, yaitu sebagai berikut:

1. Kurangnya kesadaran masyarakat dalam mentaati peraturan.

2. Ketidaktahuan masyarakat akan proses atau mekanisme dalam pengurusan izin minuman beralkohol.

3. Tidak adanya biaya yang dimiliki oleh pelaku usaha dalam mengurus surat izin usaha perdagangan minuman beralkohol (SIUP-MB).

4. Lamanya waktu yang diperlukan dalam mengurus SIUP-MB.

5. Tidak lengkapnya persyaratan yang dimiliki perusahaan atau pelaku usaha dalam mengurus SIUPMB.

6. Kurangnya sosialisasi dari pemerintah mengenai pentingnya perizinan minuman beralkohol.

Faktor-faktor tersebut diatas merupakan faktor yang menyebabkan perusahaan atau pelaku usaha perdagangan minuman beralkohol tidak memiliki surat izin usaha perdagangan minuman beralkohol atau SIUP-MB dalam menjalankan kegiatan usahanya. Padahal, dengan adanya surat izin usaha perdagangan minuman beralkohol akan ada banyak manfaat yang akan didapatkan oleh perusahaan atau pelaku usaha, seperti mendapatkan kepastian hukum dan kepastian berusaha dalam menjalankan kegiatan usahanya, adanya kepastian hak yang didapatkan perusahaan, dan memudahkan untuk mendapatkan fasilitas-fasilitas tertentu yang berhubungan dengan kegiatan usaha yang dilakukan. Mengenai pengenaan sanksi hukum terhadap pelaku usaha atau distributor yang memperdagangkan minuman beralkohol yang tidak 
mempunyai surat izin usaha perdagangan minuman beralkohol atau SIUP-MB, perusahaan atau distributor tersebut dapat dikenakan sanksi administratif. Sanksi administratif tersebut dapat berupa teguran lisan dan/atau tertulis, dan penghentian sementara proses produksi, distribusi, maupun penjualan minuman beralkohol. Pengenaan sanksi tersebut dilaksanakan sesuai dengan ketentuan peraturan perundangundangan yang berlaku. Sedangkan pemberian sanksi hukum terhadap perusahaan atau distributor yang tidak memiliki SIUP-MB berdasarkan Peraturan Menteri Perdagangan Republik Indonesia Nomor 20/MDAG/PER/4/2014 Tentang pengendalian dan pengawasan terhadap pengadaan, peredaran, dan penjualan minuman beralkohol pasal 43 Ayat (1). Pengenaan sanksi administratif tersebut diatas belum disebutkan secara jelas terkait dengan jangka waktu pengenaan sanksi dan mekanisme pengguguran sanksi tersebut. Meskipun sosialisasi yang dilakukan oleh pemerintah mengenai pentingnya perizinan tentang minuman beralkohol saat ini masih sangat kurang, namun bukan berarti informasi mengenai perizinan tersebut tidak bisa dicari dan dipahami. Perusahaan atau pelaku usaha bisa datang langsung ke kantor pelayanan perizinan daerah setempat untuk menanyakan mengenai proses atau mekanisme dalam pengurusan izin usaha tersebut.

\section{SIMPULAN DAN SARAN}

\section{Simpulan}

Dari pembahasan dan analisa yang telah dipaparkan diatas, dapatlah ditarik kesimpulan bahwa mekanisme pemberian izin peredaran minuman beralkohol berdasarkan Peraturan Gubernur Bali Nomor 1 Tahun 2020 yaitu perusahaan atau pelaku usaha harus menempuh prosedur dan memenuhi persyaratan-persyaratan tertentu terlebih dahulu dalam memohon SIUP-MB. Selanjutnya perusahaan atau pelaku usaha mengajukan permohonan izin tersebut kepada Dinas Perdagangan dan Perindustrian Provinsi selaku instansi pemerintahan yang berwenang mengeluarkan izin. Setelah dilakukannya penerbitan usaha oleh Dinas Perdagangan dan Perindustrian, barulah perusahaan atau pelaku usaha tersebut dapat melakukan usaha perdagangan yang dikehendaki, tanpa adanya surat izin usaha tersebut perusahaan tidak dapat mengoperasikan kegiatan usahanya dan perusahaan dapat dikenai sanksi administratif sesuai dengan peraturan perundang-undangan yang berlaku.

Implikasi Peraturan Gubernur Bali Nomor 1 Tahun 2020 Tentang tata kelola minuman fermentasi dan/atau destiasi khas bali terhadap pelaku usaha perdagangan minuman beralkohol sangat besar dirasakan manfaatnya, khususnya bagi para perajin atau petani minuman fermentasi dan/atau destilasi khas bali. Karena dengan adanya Peraturan Gubernur tersebut para perajin atau petani memiliki kepastian hukum dan kepastian berusaha dalam melakukan kegiatan produksi minuman fermentasi dan destilasi khas bali. Berbeda jauh dengan sebelum adanya Peraturan Gubernur ini, sebelum adanya Peraturan Gubernur ini para perajin kerap dirazia polisi dikarenakan mereka dianggap melakukan kegiatan yang ilegal atau melanggar hukum. Namun dengan adanya Peraturan Gubernur Nomor 1 Tahun 2020 ini para pelaku usaha minuman beralkohol sangat merasa terbantu, dikarenakan mereka telah memiliki payung hukum dalam menjalankan kegiatan usahanya. Meskipun minuman fermentasi dan/atau destilasi khas Bali telah dilegalkan melalui Peraturan Gubernur Bali Nomor 1 Tahun 2020, para distributor atau perajin minuman beralkohol tetap diwajibkan untuk memiliki surat izin usaha (SIUP-MB). Pemerintah melalui Dinas Perdagangan dan Perindustrian memiliki kewenangan dalam melakukan pembinaan dan pengawasan terhadap produsen, distributor, sub distributor, pengecer, dan penjual langsung yang memperdagangkan minuman beralkohol. Bagi pelaku usaha yang tidak memilki izin usaha perdagangan minuman beralkohol dapat dikenai sanksi administratif berupa teguran lisan dan/atau tulisan, penghentian sementara proses produksi, distribusi, maupun penjualan, dan pencabutan SIUP atau izin teknis.

\section{Saran}

Pemerintah selaku penyelenggara pelayanan publik hendaknya harus lebih giat lagi untuk turun ke lapangan guna untuk mensosialisasikan mengenai pentingnya perizinan usaha minuman beralkohol (SIUP-MB) kepada masyarakat khususnya pelaku usaha. Karena saat ini masih banyak perusahaan atau pelaku usaha yang tidak memiliki izin dalam menjalankan kegiatan usahanya, dikarenakan ketidaktahuan para pelaku usaha mengenai proses atau mekanisme dalam pengurusan izin usaha. 
Pelaku usaha atau Distributor diharapkan untuk selalu mentaati segala peraturan dan ketentuan yang telah ditetapkan oleh pemerintah selaku pemberi izin mengenai izin usaha perdagangan minuman beralkohol, demi terciptanya ketertiban dan kelancaran dari kegiatan usaha yang dilakukan. Karena dengan memiliki izin, perusahaan tersebut telah memiliki tanda bukti yang sah menurut hukum yang diberikan oleh pemerintah untuk dapat melakukan kegiatan usaha perdagangan.

\section{DAFTAR PUSTAKA}

Alfianti, Luffita. 2018. "Upaya Pemerintah Daerah Dalam Pengendalian Produksi Minuman Beralkohol Tradisional." Yuridika: Fakultas Hukum Universitas Airlangga 33(1).

Cahyo, Ryan Putra Dwi and Satria Adhitama. 2019. "Tinjauan Atas Pengawasan Terhadap Perizinan Pengusaha Tempat Penjualan Eceran Minuman Beralkohol.” Jurnal Perspektif Bea Dan Cukai 2(2).

Hartati Nurwijaya and Zullies Ikawati. 2009. Bahaya Alkohol Dan Cara Mencegah Kecanduannya. Jakarta: PT. Elex Media Komputindo.

Hasyim, Farida. 2018. Hukum Dagang. Jakarta: Sinar Grafika.

Huda, Ni'matul, Jamaludin Ghafur, and Ali Ridho. 2015. "Urgensi Pengaturan Peredaran Minuman Beralkohol Di Daerah Istimewa Yogyakarta.” Jurnal Hukum Ius Quia Iustum 22(1):76-96.

Khumairoh, Ananda. 2016. "Pelaksanaan Kebijakan Pemerintah Kota Bandar Lampung Tentang Pengendalian Dan Pengawasan Terhadap Pengadaan Dan Penjualan Minuman Beralkohol Di Minimarket.” Universitas Lampung.

Lestari, Tri Rini Puji. 2016. "Menyoal Pengaturan Konsumsi Minuman Beralkohol Di Indonesia." Aspirasi: Jurnal Masalah-Masalah Sosial 7(2).

Maryadi, Ilham Dwi, Ahmad Bahiej, and Tahir. 2016. "Penegakan Hukum Terhadap Peredaran Minuman Beralkohol Di Kabupaten Bantul (Studi Atas Implementasi Peraturan Daerah Kabupaten Bantul Nomor 2 Tahun 2012 Tentang Pengawasan, Pengendalian, Pengedaran, Dan Pelanggaran Penjualan Minuman Beralkohol Di Kabupaten.” Universitas Islam Negeri Sunan Kalijaga Yogyakarta.

Nuriyanto A. Daim. 2019. Hukum Perizinan, Pelayanan Perizinan Terpadu Barbasis Teknologi Informsi Dalam Perspektif Good Governance. Yogyajarta: Laksbang Justitia.

Patawari and Affandi Makmur Limpo. 2020. "Analisis Yuridis Sosiologis Terhadap Pelaksanaan Peraturan Daerah Nomor 8 Tahun 2006 Tentang Larangan Peredaran Minuman Beralkohol Dan Pengawasannya Di Kabupaten Jeneponto." Khatulistiwa Law Review 1(1).

Sjacran Basah. 1995. Pencabutan Izin Salah Satu Sanksi Hukum Administrasi. Surabaya.

Waluyo. 2002. Hak Penguasaan Tanah Land Reform. Jakarta: Wacana Pustaka.

Zanivah, Dewi Irmayanti, I. Gusti Ngurah Wairocana, and I. Ketut Sudiarta. 2016. "Pengendalian Peredaran Minuman Beralkohol Di Wilayah Hukum Polresta Denpasar.” Kertha Negara 4(6). 